\title{
Intellectual Property Valuation and Accounting
}

\section{Jeffrey E Jarrett ${ }^{*}$}

Management Science and Finance, University of Rhode Island, 7 Lippitt Road, Kingston, RI 02881, USA

\begin{abstract}
Reporting revenue from intellectual property is a problem of revenue recognition. Although current reporting standards may prescribe rules and regulations for such items as matching and revenue recognition or what is often referred to as the realization postulate in accounting. Financial reporting is the method by which accountants aid business in recognizing their accomplishments. Recognizing future performance is a goal by most reporting methods are merely designed to recognize past cash movement and equivalents as part of the history of a firm but also to evaluate present performance by traditional reporting methods? We evaluate these methods based on traditional accounting theory to facilitate the improvement in accounting methods. We define Intellectual Property (IP) as any product of intellect that the law protects from unauthorized use by others. These items include patents, copyrights, trademarks and trade secrets are considered to be the products of intellectual property. To account for these items is a serious problem and is the main subject of this study.
\end{abstract}

Keywords: Intellectual property; Recognition; Realization; Matching

\section{Introduction}

Intellectual property (IP) refers to creations of the intelligence for which a firm or entity is assigned to designated owners by law [1]. Intellectual property rights (IPRs) are the protections granted to the creators of IP, and include patents, trademarks, copyright, design rights and often referred to, and in some jurisdictions trade secrets [2]. Artistic works including music and literature, as well as discoveries, inventions, words, phrases, symbols, and designs can all be protected as intellectual property.

In previous manuscripts, Brief and Owen [3], Jarrett [4-6], Barnea and Sadan [7] and Bierman [8] produced an ongoing theory concerning the appropriate method by which accounting can evaluate the proper method for matching costs with revenues and realizing the anticipated revenues associated with operations. Their conclusions basically stated that such methods are the same and are included in what one refers to estimation theory.

Current accounting methods consider a firm's image is thought of as its collection of tangible assets. Since IP, do not represent tangible assets they represent those assets that are not fully represented in a firm's position statements or balance sheets. They are not cash flows in the historical sense so they would not appear in a cash flow position report but they would affect the reasonable value of a firm. Often "branding" processes are methods by which a firm may achieve value associated with its trademarks, copyrights and patents. The tangible value of these assets are always in dispute because an accountant would be expected to "estimate" the intrinsic value of the trademark, copyright or patent.

How does this become fully an estimation problem in accounting? Simply put, how does one account for the revenue associated with a patent. The patents will give rise to a product which will be manufactured by the firm or outsourced to a foreign firm for production, distribution and all other operations going into the physical end product including marketing operations for packages and distribu6tion including stock of shelves or marketing on the internet. If the patent has a value when to we match the costs with the revenues from sales of the final product and when do we do it.

\section{What do We do about Intangibles?}

Recognition of IP which is the recognition of intangibles is not unknown to the accounting profession but the estimation problem associated with accounting for intangibles is a very difficult process. Needless to say, that both the Security and Exchange Commission and the Financial Accounting Standards board endeavor to find a solution to the problem. For example when Mergers and Acquisitions occur (M\&A), often supplementary IP reports are issued during this period. The IP report may value fairly the value of the trademark, copyright and /or patent. To separately list the IP's on its own does not necessarily reduce the problem of valuing IP, but recognizes that these items do have value in M\&A activity. Since accounting has proceeded successfully in valuing tangible assets, the difficulty of IP activity valuation is not reduced. For example, accounting recognizes business items at their price in a transaction; on the other hand the value of an IP cannot always be values in this way. In a merger, the difference in the value of a firm may be a starting point for estimating the value of the IP. If the only difference is reflected in the merger as opposed to the previous value of the firms merging may be simply the value of the IP. However, this puts a great deal of stress on cost accounting and accounting for mergers leaving accounting with a great deal of difficulty. The IP if its associated with a patent may change rapidly if a new patent is produced which seriously reduces the value of the original patent. Furthermore, would FASB and/or SEC accounting rules and regulations permit this to even be accounted for by traditional standards?

\section{Good Will?}

Usually, when accountants speaks about valuing IP they tend to use the term "Goodwill." Often "goodwill" is thought to be the residual which a buyer is ready to value (pay for) in excess of the value of the tangible assets. See for example, White et al. [9] to ascertain traditional methods] Note the definition of goodwill by this residual method at

*Corresponding author: Jarrett EJ, Professor, Management Science and Finance, University of Rhode Island, 7 Lippitt Road, Kingston, RI 02881, USA, Tel: +401 (874) 4169; Fax: 401 (874) 4312; E-mail: jejarrett133@gmail.com

Received February 07, 2017; Accepted March 10, 2017; Published March 18 2017

Citation: Jarrett JE (2017) Intellectual Property Valuation and Accounting. Inte Prop Rights. 5: 181. doi: 10.4172/2375-4516.1000181

Copyright: ( 2017 Jarrett JE. This is an open-access article distributed under the terms of the Creative Commons Attribution License, which permits unrestricted use, distribution, and reproduction in any medium, provided the original author and source are credited. 
least bring some scientific method in valuing intangible assets such as IP. Note also, it does have the same vagueness that is attributable to valuing IP as noted in the previous section. The vagueness that characterizes and justifies a higher price for a firm is included in goodwill. The result is often to make not comparable the goodwill of firms but also creates a very poor standard for evaluating the IP. The challenge for accounting is to accept that value for IP is related to future cash flow from the sale of products associated with the IP. For example, the trademark may command a higher price for the items sold creating additional revenue. The higher transactions price yield revenue beyond what would be raised if there was no trademark or to say the transactions price may be equal to the generic price for the same item. That is to say, is the difference in price between a proprietary drug and a generic drug may be due only to the perception of the customer. Goodwill has no place here in this scenario.

Goodwill as defined above will not come up with a universal definition of valuing the IP. The value of IP is not goodwill in a wide variety of circumstances. Balance sheets and position statements of firms and other entities should not confuse the terms. Inherent values of IP need to be associated with the matching and realization principles which require estimation theory.

\section{Estimation Theory in Accounting}

Estimation theory in accounting principles permitted the restructuring and focus of accounting on the jointness of costs and revenues. No longer has the accountant emphasize a particular point in time for matching or revenue recognition of costs and revenues prior to the collection and distribution of cash. We focus now on the overall rate of return associated with the firm or entity. Jarrett previous [10] noted that rules for financial accounting should not ignore the accounting principle of conservatism but should include ways in which one evaluates the economic value of future earnings which enable one to produce a rate of return. IP does induce higher rates of return for firms and accounting must develop methods for specifically evaluating IP items individually. Using present values of future income can aid one to properly evaluate the value of IP's to a firm as noted before by Bierman [8] certainly can aid in the estimation problem in finding values for IP in balance sheets [11].

\section{Conclusion}

In this analysis we present arguments concerning the likely futility shown in past accounting practices in attempting to value IP in financial statements of firms and other entities. Merely listing IP does not show their importance especially when patents, trademarks and other IP age and become less significant in the valuation of a firm. Using Goodwill and measuring it by crude methods will also provide little aid in solving the valuation problems of this type. Estimation is the answer and accounting should attempt to solve these problems without violating standard account methods such as lower of "cost or market." This is often dropped as a rule when in some nations governments violate accounting standard to aid in the financing of firms they desire to help. The manuscript by Lev (2001) can also introduce some notions as to the valuation of intangibles.

\section{References}

1. Krugman P (2015) “TPP at the NABE”, Paul Krugman Blog

2. WTO (2016) What are intellectual property rights?" World Trade Organization.

3. Brief R, Owen J (1970) The Estimation Problem in Financial Accounting Journal of Accounting Research 8: 167-177.

4. Jarrett JE (1971) The Principles of Matching and Realization as Estimation Problems. Journal of Accounting Research 9: 378-382.

5. Jarrett JE (1974) Bias in Adjusting Asset values for Changes in the Price Level: An Application of Estimation Theory. Journal of Accounting Research 12: 63-66.

6. Jarrett JE (1983) The Rate of Return from Interim Financial Reports, Journal of Business Finance and Accounting 10: 289-294.

7. Barnea A, and Sadan, S (1974) On the Decomposition of the Estimation Problem in Financial Accounting. Journal of Accounting Research 12: 197-203.

8. Bierman Jr H (1971) Discounted Cash Flows, Price Level Adjustments and Expectations. The Accounting Review 693-99.

9. White GI, Sandhi AC, Fried D (1994) The Analysis and Uses of Financial Statements (3rdedn). John Wiley, New York.

10. Jarrett JE (2016) The Problems of Accounting Reporting False Information and Estimation, Intel Prop Rights. S1: 007.

11. Lev B (2001) Intangibles: Management, Measurement and Reporting, Bookings Institution Press, USA. 